Agnieszka Biernat-Jarka

Warsaw University of Life Sciences - SGGW

\title{
ASSESSMENT OF GREENING IN THE CONTEXT OF PROVIDING ENVIRONMENTAL PUBLIC GOODS IN AGRICULTURE
}

The article discusses the concept of providing environmental public goods through agriculture. The theoretical goal of the discussion was to present the concept of greening under the EU's Common Agricultural Policy. This concept was developed on the basis of available literature and from EU and Polish documents. The concrete goal is to assess greening instruments in terms of their implementation and compliance by farmers. A review of the available literature on the subject allows the assumption that the greening instrument implemented under the CAP has contributed to an intensification of activities by farmers in the field of environmental protection. The article was prepared based on source materials, monographs and scientific articles as well as Eurostat data. The article also presents the results of Eurobarometer surveys that show the expectations of EU citizens towards the European Union's CAP in the field of environmental and climate protection. Results of surveys have shown that on the one hand, the European Union should be responsible for ensuring healthy and safe food products for consumers, while on the other hand the goal of the Common Agricultural Policy should be to ensure an appropriate standard of living for farmers.

Key words: Common Agricultural Policy, public goods, greening, environmental protection, Poland, European Union

JEL code: Q 14, Q18

\section{Introduction}

The current Common Agricultural Policy of the EU provides financial support for farmers, encouraging them to carry out activities beneficial for the natural environment. Currently, particular attention in the functioning of the Common Agricultural Policy is attached to linking the financing possibilities of individual instruments, e.g. direct payments or actions under rural development policy with the provision of environmental public goods. Public goods are defined as those which are not supplied or insufficiently supplied by the market. The use of these goods by one person does not limit or exclude the use of others at the same time ${ }^{1}$. Public goods are available to everyone, including those who have not paid for them. They consciously use these goods and avoid bearing any costs arising from their use. Without the state's interference in the production and supply of public goods, there could be a situation where, despite the high demand for a

\footnotetext{
${ }^{1}$ Stiglitz J., E.: Ekonomia sektora publicznego, PWN Warszawa 2004, p. 150; Samuelson P.,S., Nordhaus W., D.: Ekonomia, tom 2, PWN Warszawa 1996, p. 239; Acocella N.: Zasady polityki gospodarczej, PWN, Warszawa 2002, p. 131; Altvater E. Public goods for human security, http://revistas.ucm.es/index.php/PAPE/article/viewFile/PAPE0707220001A/25673, Papeles del Ester, 14 (2007), 1-19;
} 
given good, production would not take place ${ }^{2}$. Environmental goods supplied under the EU's agricultural policy include ${ }^{3}$ : biodiversity, agricultural landscape, soil conservation, proper water relations. As part of the current Common Agricultural Policy, starting from 2013, payment of direct payments was made as well as the possibility of using specific rural development programs with activities beneficial for the natural environment. First of all, we should mention here the payment for greening, which depends on meeting the requirements in the field of crop diversification, maintenance of permanent grassland (TUZ) and the allocation of part of the farm area for ecological purposes ${ }^{4}$. An important role in the payment system is also compliance by farmers with the so-called good agricultural culture, which includes provisions for proper management of agricultural land. In this way, the aim is to maintain biological biodiversity by protecting natural habitats, animal and plant species in Natura 2000 areas. In addition to direct payments, the system of measures proposed to farmers under the Rural Development Program ${ }^{5}$ is very important in the delivery of public goods. The most important instruments that matter in providing environmental public goods are: restoring and protecting as well as enriching biodiversity in selected areas, improving water management and preventing soil erosion. Extensive land use in less-favored areas or the construction of ecological corridors and enclaves contribute to the preservation of landscape values and promote the biodiversity of rural areas ${ }^{6}$.

\section{The concept of "greening" within the CAP}

Greening payments were introduced as a result of the Common Agricultural Policy (CAP) reform of 2013. The European Commission has stated that it is necessary to support farms in exchange for their use of activities contributing to the achievement of ecological goals in the field of improving environmental impact. Greening can be described as a mechanism of positive agri-environmental public goods ${ }^{7}$. It is implemented through the diversification of crops, maintaining permanent grassland, including traditional orchards, which are slightly dense and cover the area of the permanent grassland (TUZ), and maintaining pro-ecological areas on agricultural land. The maintenance of permanent grassland greatly contributes to the preservation of biodiversity, carbon absorption and soil protection. Diversification, in contrast, improves soil quality, while establishing ecological focus areas also ensures protection and enhancement of biodiversity, reduction of pollution flowing into surface waters and improvement of soil resistance.

\footnotetext{
${ }^{2}$ Wojtyna A.: Nowoczesne państwo kapitalistyczne a gospodarka, Teoria i praktyka, PWN Warszawa 1990, Stiglitz J., E.: Ekonomia sektora publicznego, PWN Warszawa 2004, p. 94

${ }^{3}$ Cooper T., Kaley H., Baldock D.: Conceptual Framework on Public Goods Provided Through Agriculture in the EU. Working Document of the Technical Working Group Public Goods, European Network for Rural Development, 4/2009, p. 14-28.

${ }^{4}$ System płatności bezpośrednich w latach 2015-2020, MRiRW, Warszawa maj 2015, p. 1-10.

${ }^{5}$ Program Rozwoju Obszarów Wiejskich na lata 2014-2020 (PROW 2014-2020), Warszawa, 12 grudnia 2014

${ }^{6}$ Biernat-Jarka A.: Dobra publiczne w rolnictwie w nowej perspektywie finansowej Unii Europejskiej, Zagadnienia Ekonomiki Rolnej, IERiGŻ, Warszawa 1/2016, p. 144-154

${ }^{7}$ Jaroszewska J.: Zazielenienie jako przykład internacjonalizacji efektów zewnętrznych - agrośrodowiskowych dóbr publicznych, $Z$ badań nad rolnictwem społecznie zrównoważonym, Monografie Programu Wieloletniego, IERiGŻ, Warszawa 40/2017, p. 72.
} 
In Poland, farmers participating in the direct payments system must submit applications for greening payment. Farms with an area of up to 10 ha of agricultural land can use this system without being obliged to comply with greening requirements. These requirements also do not apply to organic farms.

Crop diversification is based on the fact that when arable land covers 10-30 ha of land on a farm, at least two plant species must be cultivated and the main crop must not constitute more than $75 \%$ of the land. On a farm with over 30 ha of arable land, at least three different crops must be cultivated, and the main crop must not constitute more than $75 \%$ of the area, and in total two crops may not cover more than $95 \%$ of this land. Farms where cultivated grasses or other herbaceous plants and / or fallow land constitute more than $75 \%$ of the arable land, and with additional land that does not constitute more than $30 \mathrm{ha}$, are exempt from diversification. In addition, diversification may be exempted for farms in which $75 \%$ of arable land is permanent grassland and / or grass or other herbaceous forage, with any additional arable land not to exceed 30 ha. The diversification obligation also excludes farms where organic production is carried out on part of the arable land, while the remaining arable land area is less than 10 ha. Farmers with more than 15 ha of arable land must allocate $5 \%$ of their land for pro-ecological purposes. These areas may consist of fallow land, buffer zones, wooded areas, agroforestry areas, but need also to use catch crops or winter green cover. The main goal of maintaining ecological focus areas is to maintain and increase biodiversity ${ }^{8}$.

Another greening measure is to maintain permanent grassland, which also contributes to the conservation of biodiversity. Therefore, a ban on the conversion of permanent grassland into arable land was introduced in Natura 2000 areas. An appropriate share of permanent grassland must be maintained in a nation's total area of agricultural land, and may not decrease by more than 5\% from 2015 levels. If such a situation occurs, Member States must oblige their farmers to restore their grassland to permanent pasture? .

Regarding ecological focus areas, so-called "productive" and "non-productive" ecological areas can be defined. Productive ecological areas include catch crops, the use of nitrogen-fixing crops, short rotation coppices or the so-called agroforestry system. On the other hand, pro-ecological areas that do not include agricultural production are fallow land, buffer zones, wooded areas, landscape elements, i.e. hedges and wooded belts, ditches, ponds, coppice and mid-field balks ${ }^{10}$.

\footnotetext{
${ }^{8}$ Regulation (EU) No 1307/2013 of the European Parliament and of the Council of 17 December 2013 laying down provisions on direct payments to farmers under support schemes under the common agricultural policy and repealing Council Regulation (EC) No 637/2008 and Council Regulation (EC) No. 73/2009, Official Journal of the European Union, Article 44 http://g.ekspert.infor.pl/p/_dane/akty_pdf/E0L/2013/347/608.pdf\#zoom=90

${ }^{10}$ Evaluation study of the payment for agricultural practices beneficial for the climate and the environment, Alliance Environnementand the Thünen Institute November-2017-ALLIANCE ENVIRONNEMENT, European Union, 2017 https://ec.europa.eu/agriculture/sites/agriculture/files/fullrep_en.pdf, str. 1-5
} 


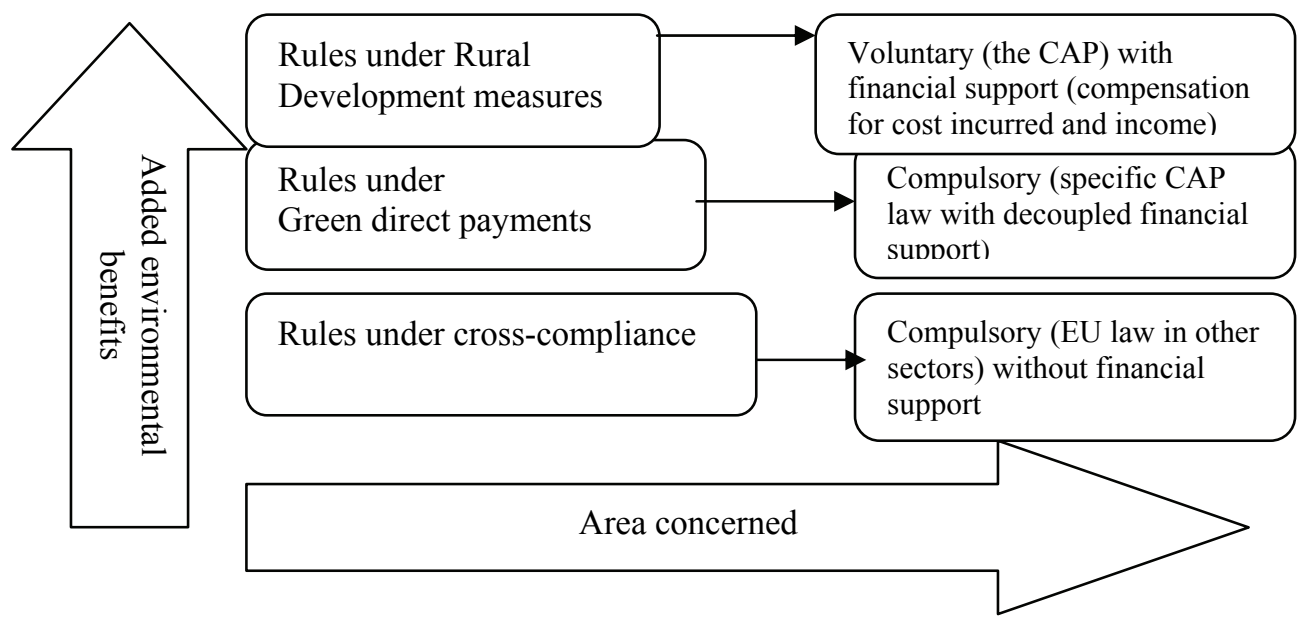

Figure 1. The new greening architecture of the CAP

Source: Commission Staff Working document, Review of greening after one year, Brussels, 22.6.2016 SWD (2016) 218 final PART 1/6, European Commission.

In addition to the greening mechanism, it is important to remember that farmers, in compliance with good agricultural standards, are required to comply with the basic principles of environmental protection, climate change and animal welfare. If these activities are not carried out, the payment will be reduced by 1 to $5 \%$. Environmental measures implemented under the CAP are shown in Figure 1. As shown in Figure 1, cross compliance applies to all farmers benefiting from direct payments. Compliance with these rules does not involve additional financial resources, they must be completed by farmers as mandatory. Further greening activities (second level) are also mandatory, applied according to the specific principles described in the article, for which farmers receive payments, and the last highest level of additional support for environmental practices that are implemented under the Rural Development Plan.

\section{Material and methods}

The theoretical goal of the discussion was to present the concept of greening under the EU's Common Agricultural Policy. The concrete goal is to evaluate the greening program implemented by farmers in individual EU countries. The EU budget for 20142020 combined the receipt of financial support by farmers with compliance to specific standards and regulations for the natural environment. A review of the available literature on the subject indicated that the greening instrument implemented within the CAP contributed to more intensive greening activities by farmers, which was shown by an increase in the land area of crops consistent with greening (permanent grassland and ecological focus areas). The article was prepared on the basis of source materials, monographs and scientific articles as well as Eurostat data. The article also presents the results of Eurobarometer surveys, which show the expectations of EU citizens regarding 
CAP activities for environmental and climate protection. The research was carried out in December, 2016. It was based on approximately 28,000 direct questionnaire interviews, including over 1,000 respondents in Poland.

\section{Results and Discussion}

\section{Financing greening within the CAP}

After the introduction of the greening payment, the total amount of financial resources allocated to direct payments in the European Union did not change, only transfers between individual types of payments were affected. Of the approximately EUR 40 billion allocated to direct payments, EUR 11.7 billion (around 30\% of all direct payments and almost $8 \%$ of the total EU budget) are green funding. Farmers in the EU received, on average, around 80 euros per hectare per year in 2016 for greening payments. In Poland in 2016, PLN 15 billion were allocated for direct payments, of which more than 4 billion PLN were for greening. The greening payment per ha in 2016 was PLN 309.77, equivalent to EUR 71.34/ha. Responsibility for the use of greening in the EU is based on shared management, i.e. the European Commission is responsible for implementing the EU budget, and tasks related to the implementation of payments are delegated to individual Member States. Agencies responsible for the direct payment system are required to collect applications from farmers, conduct administrative checks of beneficiaries, and calculate and pay the corresponding payments.

\section{Assessment of greening as an instrument for achieving the objectives of the CAP}

The greening payment was introduced in the current financial perspective as an instrument intended to contribute to the introduction of production methods that have a positive impact on the natural environment.

The justification for greening by the European Commission was to reward farmers for providing public goods for which the market is unable to pay. However, the question arises as to whether the introduction of greening has actually contributed to an increase in the area of permanent grassland and ecological crops.

In order to verify the thesis, the author analyzed statistical data showing changes in the area of permanent grassland and pro-ecological areas in all EU countries in 2016. EU Member States, as part of the 2013 reform, were obliged to maintain an appropriate ratio of permanent grassland area to overall agricultural area, which is referred to as the reference index. The rate of permanent grassland in the EU is currently around $30 \%$, an increase of $1.5 \%$ compared to $2007-2014$.

This increase, however, does not necessarily mean a real increase in the area of permanent grassland; the decrease in the area of declared permanent grassland (counter) (from 47 million ha in 2007-2014 to 44 million ha in 2016) occurred more slowly than the decrease of the denominator, i.e. arable land (from 164 million ha in 2007-2014 to 145 million ha in 2016). As shown in Table 1, in most EU member states the reference ratio of permanent grassland for 2015-2020 was at a lower level than the actual percentage of permanent grassland in 2016. Only a slightly lower percentage of permanent grassland compared to the reference indicator could be seen in nine member countries, e.g. Great Britain, Estonia or Portugal, while the maximum differences were 
3pp. On average, for the entire EU, the actual percentage of permanent grassland area was only $0.1 \%$ lower than the assumed reference indicator for 2015-2020.

Table 1. Permanent grassland and ecological land area in EU countries, in 2016

\begin{tabular}{|c|c|c|c|c|c|c|c|}
\hline \multirow[b]{2}{*}{ Countries } & \multicolumn{3}{|c|}{ Permanent grassland } & \multicolumn{4}{|c|}{ Ecological focus areas } \\
\hline & $\begin{array}{c}\text { Permanent } \\
\text { grassland } \\
\text { declared, } \\
\text { in } 2016\end{array}$ & $\begin{array}{l}\text { Reference } \\
\text { indicator } \\
\text { for } 2015 \text { - } \\
2020\end{array}$ & $\begin{array}{l}\text { Percentage } \\
\text { of } \\
\text { permanent } \\
\text { grassland } \\
\text { in } 2016\end{array}$ & $\begin{array}{l}\text { Arable land } \\
\text { covered by } \\
\text { the obligation } \\
\text { in the area of } \\
\text { environmental } \\
\text { protection }\end{array}$ & $\begin{array}{l}\text { Required } \\
\text { ecological } \\
\text { areas: } 5 \% \text { of } \\
\text { arable land } \\
\text { covered by the } \\
\text { obligation in } \\
\text { the terms of } \\
\text { ecological } \\
\text { focus areas }\end{array}$ & $\begin{array}{l}\text { Ecological } \\
\text { focus } \\
\text { areas } \\
\text { declared }\end{array}$ & $\begin{array}{l}\text { ecological } \\
\text { focus areas } \\
\text { declared } \\
\text { above the } \\
\text { required } \\
\text { minimum }\end{array}$ \\
\hline Belgium & 448987 & $33,7 \%$ & $34,2 \%$ & 706984 & 35349 & 53315 & $51 \%$ \\
\hline Bulgaria & 430730 & $11,7 \%$ & $11,6 \%$ & 2992629 & 149631 & 210043 & $40 \%$ \\
\hline $\begin{array}{l}\text { Czech } \\
\text { Republic }\end{array}$ & 568829 & $18,4 \%$ & $18,6 \%$ & 2396918 & 119846 & 178209 & $49 \%$ \\
\hline Denmark & 187406 & $7,7 \%$ & $7,8 \%$ & 2106321 & 105316 & 108850 & $3 \%$ \\
\hline Germany & 4225999 & $26,9 \%$ & $26,7 \%$ & 10738721 & 536936 & 681520 & $27 \%$ \\
\hline Estonia & 191413 & $28,0 \%$ & $24,5 \%$ & 399630 & 19981 & 39807 & $99 \%$ \\
\hline Ireland & 4146476 & $91,1 \%$ & $92,3 \%$ & 317777 & 15889 & 39117 & $146 \%$ \\
\hline Greece & 1113762 & $34,3 \%$ & $32,1 \%$ & 672977 & 33649 & 111797 & $232 \%$ \\
\hline Spain & 5188284 & $26,4 \%$ & $26,9 \%$ & 9337789 & 466889 & 1497885 & $221 \%$ \\
\hline France & 8308807 & $31,2 \%$ & $31,4 \%$ & none & none & none & none \\
\hline Croatia & 128516 & $12,8 \%$ & $13,6 \%$ & 523344 & 26167 & 73255 & $180 \%$ \\
\hline Italy & 1352638 & $15,7 \%$ & $16,1 \%$ & 3352576 & 167629 & 307295 & $83 \%$ \\
\hline Cyprus & 2622 & $2,3 \%$ & $2,0 \%$ & 1862 & 3093 & 9123 & $195 \%$ \\
\hline Latvia & 320117 & $22,3 \%$ & $22,8 \%$ & 823932 & 41347 & 81369 & $97 \%$ \\
\hline Lithuania & 695077 & $21,5 \%$ & $25,9 \%$ & 2103701 & 105185 & 251038 & $139 \%$ \\
\hline Luxembourg & 61497 & $51,3 \%$ & $53,0 \%$ & 47818 & 2391 & 3668 & $53 \%$ \\
\hline Hungary & 576847 & $12,6 \%$ & $12,4 \%$ & 3348571 & 167429 & 298598 & $78 \%$ \\
\hline Netherlands & 690270 & $40,6 \%$ & $40,5 \%$ & 582736 & 29137 & 60378 & $107 \%$ \\
\hline Austria & 904038 & $43,4 \%$ & $43,9 \%$ & 305859 & 15293 & 20837 & $36 \%$ \\
\hline Poland & 1849142 & $14,3 \%$ & $15,5 \%$ & 5791052 & 289553 & 408652 & $41 \%$ \\
\hline Portugal & 893592 & $38,2 \%$ & $37,7 \%$ & 405779 & 20289 & 38882 & $92 \%$ \\
\hline Romania & 1675808 & 23,9 & 22,3 & 5103229 & 255161 & 383267 & $50 \%$ \\
\hline Slovenia & 234513 & 56,1 & 56,8 & 70803 & 3540 & 5705 & $61 \%$ \\
\hline Slovakia & 390167 & 23,3 & $23,0 \%$ & 1220965 & 61048 & 89208 & $46 \%$ \\
\hline Finland & 134006 & 6,4 & 6,6 & 413588 & 20679 & 27312 & $32 \%$ \\
\hline Sweden & 424332 & 14,3 & 16,8 & 1379908 & 68995 & 118308 & $71 \%$ \\
\hline $\begin{array}{l}\text { United } \\
\text { Kingdom }\end{array}$ & 8547962 & $64,8 \%$ & $61,9 \%$ & 4795556 & 239778 & 497274 & $107 \%$ \\
\hline Total & 41691838 & $30,2 \%$ & $30,1 \%$ & 60004114 & 3000206 & 5594727 & $86 \%$ \\
\hline
\end{tabular}

* The table does not include Malta, due to the lack of permanent grasslands, and in France there is no complete data on ecological focus areas.

Source: author's own elaboration based on Eurostat.

In turn, the area of ecological crops on average across the EU in 2016 accounted for over $86 \%$ more than the required minimum of these areas. Notably, countries with much higher areas of ecological focus than the assumed indicator were Greece and Spain, with over $200 \%$.

The European Court of Auditors has found that, following the introduction of greening, changes in agricultural practices only occurred on around $5 \%$ of EU 
agricultural land. According to research by Louhichi et al. ${ }^{11}$, greening had no effect on $71 \%$ of farmers who also did not incur any costs associated with its implementation. Of the nearly $30 \%$ of farmers affected by greening, only two-thirds incurred costs of EUR $25 /$ ha due to farm adaptation to these requirements. Only the costs incurred by $2 \%$ of farmers exceeded EUR 100/ha. This situation mainly concerned highly specialized farms, e.g. in vegetable production. This research also showed a very slight increase of $1 \%$ in farmers' income due to price increases as a result of reduced production volumes. As data from the European Commission show, in 2015, 24\% of farms were covered by at least one greening obligation, which was $73 \%$ of the arable land in the EU (110 million ha from 150 million ha throughout the EU). In 2016, the percentage of households with at least one commitment resulting from greening increased to $77 \%$. The Commission considers this increase to be the result of actions taken ${ }^{12}$.

According to the annual report of the Court of Auditors [S annual report on the implementation of the budget for 2016, paragraph 7.56], the introduction of the greening requirement resulted in 2016 that $1 \%$ of UAA in the EU required greater diversification and about $1 \%$ of UAA required the introduction of additional ecological focus areas. Louhichi et al. indicated that after the introduction of the greening obligation, this requirement changed agricultural practices on $4.5 \%$ of UAA, including $1.8 \%$ due to crop diversification, $2.4 \%$ due to ecological focus areas and $1.5 \%$ permanent agricultural land in the EU (around $1.2 \%$ of arable land has overlapped with ecological focus and crop diversification. $)^{13}$

The European Commission data shows that in $2015,76 \%$ of farms, including those not covered by the payment system in the European Union, were not covered by the greening obligation, which accounted for $27 \%$ of all UAAs. On the other hand, as regards beneficiaries of greening payments, $65 \%$ of farms operating on $16 \%$ of UAA were exempted.

Based on the analysis of statistical data, it can be concluded that the hypothesis that, after the introduction of greening payments there would be an increase in the area of permanent agricultural land and ecological focus areas, has not been confirmed. This means that the introduction of greening has not resulted in the need to increase the area of permanent grassland or of ecological plants in most EU member states. In turn, the cited research also shows ${ }^{14}$ that after the introduction of the greening requirement, there were no changes in agricultural holdings with agricultural practices used so far (farms met the requirements for greening or were exempted from this obligation). There is also a so-called "deadweight effect," where public funds paid to farmers for the delivery of public goods, in this case for agricultural practices beneficial for the environment, would still be delivered without support, because they are the result of farmers' normal activity or are also required by legal provisions, in this case cross-compliance. The deadweight effect within the Common Agricultural Policy exists because greening requirements

\footnotetext{
${ }^{11}$ Louhichi, K., P. Ciaian, M. Espinosa, And. Perni and S. Gomez y Paloma, Economic impacts of CAP greening: application of an EU-wide individual farm model for CAP analysis (IFM-CAP), European Review of Agricultural Economics 45(2)/2018: 205-238

${ }^{12}$ Zazielenienie - bardziej złożony system wsparcia dochodów, który nie jest jeszcze skuteczny pod względem środowiskowym, Sprawozdanie specjalne, Europejski Trybunał Obrachunkowy 2017 r., p. 26-28

${ }^{13}$ Louhichi, K., P. Ciaian, M. ... p. 205-238

${ }^{14}$ Tamże
} 
were met earlier and thus major changes in crop diversification or pro-ecological activities were not required. As demonstrated by statistical data in Poland, the requirements for greening were already met in 2014, with a surplus of about $30 \%$. And in other EU countries, on average, twice as much space as the required 5\% was allocated to ecological focus areas (Table 1). In addition, in 2016 there was an increase in the ratio of permanent grassland to $30 \%$ compared to the reference period 2007-2014, which was resulted from a decrease in the total area of arable land by 19 million ha. In addition, pasture was included in the current definition of permanent grassland, and a new type of arable land was identified: environmentally sensitive, which cover $16 \%$ of permanent grassland in the EU. However, about $96 \%$ of environmentally sensitive permanent grasslands are in the Natura 2000 area. Despite the fact that the separation of environmentally sensitive permanent grassland (TUZ) in these areas has a positive impact on biodiversity, attention should be directed more to areas located outside the Natura 2000 area.

Of the ecological focus areas reported under greening, productive areas dominated. In 2016, they constituted 58\%, with nitrogen binding crops and catch crops predominating.

Greening should add value beyond the basic requirements for receiving direct payments. However, there are also situations of overlapping greening requirements and cross-compliance, i.e. on the one hand certain pro-environmental practices are required as part of good agricultural culture, while on the other they can be declared as ecological focus areas. In some EU member states, including Poland, the requirements of good agricultural culture overlapped with pro-ecological areas in regard to maintaining buffer zones, ponds, ditches, coppices and catch crops.

The purpose of the article was also to show the level of public awareness in EU countries regarding the use of CAP instruments and their justification in the context of environmental protection. These opinions were based on the Eurobarometer opinion poll ${ }^{15}$, which was published in December 2017. These studies were conducted on a sample of over 28,000 direct questionnaire interviews. Regarding the most important obligations of farmers towards society, respondents emphasized providing healthy and safe high quality food (55\% in the EU, $48 \%$ in Poland), ensuring the welfare of farm animals (28\% in the EU and $14 \%$ in Poland), as well as protecting the environment and fighting against climate change (25\% in the EU and $15 \%$ in Poland). When asked whether problems relating to agriculture and rural areas should be dealt with at the EU, national or local level, very interesting answers were obtained. Namely, respondents stated that ensuring healthy and safe food products as well as guaranteeing food supplies should rest on the European Union (51\% of EU respondents). Also, ensuring an adequate standard of living for farmers should be part of the Common Agricultural Policy (44\% of EU respondents). When asked whether they had heard about the support that is given to farmers within the CAP, $67 \%$ of respondents answered "yes" and $61 \%$ thought that the

\footnotetext{
${ }^{15}$ Public opinion on the Common Agricultural Policy, Eurobarometer, https://ec.europa.eu/info/food-farming-
} fisheries/key-policies/common-agricultural-policy/cap-glance/eurobarometer_en (3/15/2019) 
CAP benefits not only farmers but also all Europeans. In addition, $62 \%$ of respondents said that the CAP contributes to mitigating the effects of climate change. When asked whether farmers' support at $1 \%$ of the total public expenditure of 28 Member States and almost $40 \%$ of the total EU budget is appropriate, $45 \%$ answered "yes" and $26 \%$ said that it was too low. About $44 \%$ of respondents said that this support should be higher in subsequent years, and $12 \%$ said that support should remain at the same level.

Summing up the results of the Eurobarometer research, it is necessary to emphasize the great awareness of European society regarding the Common Agricultural Policy. Over $60 \%$ of respondents are aware of the great importance of the CAP instruments carried out to mitigate the negative effects of climate change. In addition, citizens and therefore also consumers of food products are aware that proper agricultural policy makes it possible to provide healthy and safe food.

\section{Conclusions}

The aim of the article was to show whether the introduction of payments for greening within the CAP has contributed to an increase in the area of permanent agricultural land and ecological crops, which have a positive impact on the natural environment. Research has shown that the introduction of greening payments under the EU CAP has not increased the area allocated to areas that are beneficial from the environmental and climate point of view. The introduction of greening requirements meant that only $1 \%$ of UAA in the EU required land diversification and around $1 \%$ of UAA required the introduction of ecological focus areas. Does this mean that the European Commission did not make sense? The author's task was to separate whether subsidies related to environmental practices as part of direct payments resulted in greater awareness of farmers themselves that their activities could have a positive impact on the environment. Farmers know that as part of direct payments they receive funds for undertaking practices that are friendly to environmental protection and climate. They also realize that if they fail to meet these requirements, they will lower their levels of payments, which can have a significant negative impact on their income. In addition, EU citizens, as shown by Eurobarometer surveys, are highly aware of the importance of using proenvironmental instruments under the CAP. This is a promising and extremely important signal, because we know that our positive action begins with the awareness of the significance of a given problem, while without awareness, our action either does not take place or is very limited.

\section{Literature:}

Acocella N.: Zasady polityki gospodarczej, PWN, Warszawa 2002.

Altvater E. Public goods for human security, http://revistas.ucm.es/index.php/PAPE/article/viewFile/PAPE0707220001A/25673, Papeles del Ester, 14 (2007).

Biernat-Jarka A.: Dobra publiczne w rolnictwie w nowej perspektywie finansowej Unii

Europejskiej, Zagadnienia Ekonomiki Rolnej, IERiGŻ, Warszawa 1/2016, p. 144-154.

Commission Staff Working document, Review of greening after one year, Brussels, 22.6.2016

SWD (2016) 218 final PART 1/6, European Commision. 
Cooper T., Kaley H., Baldock D.: Conceptual Framework on Public Goods Provided Through Agriculture in the EU. Working Document of the Technical Working Group Public Goods, European Network for Rural Development, 4/2009.

Opinia publiczna na temat Wspólnej Polityki Rolnej, Eurobarometr, https://ec.europa.eu/info/foodfarming-fisheries/key-policies/common-agricultural-policy/cap-glance/eurobarometer_pl. Evaluation study of the payment for agricultural practices beneficial for the climate and the environment, Alliance Environnementand the Thünen Institute November -2017-ALLIANCE ENVIRONNEMENT, European Union, 2017

https://ec.europa.eu/agriculture/sites/agriculture/files/fullrep_en.pdf.

Jaroszewska J.: Zazielenienie jako przykład internacjonalizacji efektów zewnętrznych agrośrodowiskowych dóbr publicznych, $Z$ badań nad rolnictwem społecznie zrównoważonym, Monografie Programu Wieloletniego, IERiGŻ, Warszawa 40/2017

Louhichi, K., P. Ciaian, M. Espinosa, A. Perni and S. Gomez y Paloma, Economic impacts of CAP greening: application of an EU-wide individual farm model for CAP analysis (IFM-CAP),

European Review of Agricultural Economics 45(2)/2018: 205-238

Podlasiak, Z.: Ekonomiczna analiza countries, Wyższa Szkoła Studiów Międzynarodowych, Łódź 2009.

Program Rozwoju Obszarów Wiejskich na lata 2014-2020 (PROW 2014-2020), Warszawa, 12 grudnia 2014

Samuelson P.,S., Nordhaus W., D.: Ekonomia, tom 2, PWN Warszawa 1996.

Stiglitz J., E.: Ekonomia sektora publicznego, PWN Warszawa 2004.

System płatności bezpośrednich w latach 2015-2020, MRiRW, Warszawa maj 2015;

Wojtyna A.: Nowoczesne państwo kapitalistyczne a gospodarka, Teoria i praktyka, PWN

Warszawa 1990.

Commission Staff Working document, review of greening after one year, Brussels, 22.6.2016

SWD (2016) 218 final PART 1/6, European Commision

SPRAWOZDANIE KOMISJI DLA PARLAMENTU EUROPEJSKIEGO I RADY w sprawie wdrażania obowiązku w zakresie obszarów proekologicznych w ramach systemu płatności bezpośrednich z tytułu zazieleniania $\{$ SWD(2017) 121 final

Sprawozdanie roczne dotyczące wykonania budżetu za rok budżetowy 2016 (DZ. U. 2017/C 322/01 z 28.09.2017r)

Zazielenienie-bardziej złożony system wsparcia dochodów, który nie jest jeszcze skuteczny pod względem środowiskowym, Sprawozdanie specjalne, Europejski Trybunał Obrachunkowy 2017 r. Review of greening after one year, European Commission Brussels, 22.6.2016 SWD (2016) 218 final PART 3/6 Commission Staff Working Document Regulation (EU) No 1307/2013 of the European Parliament and of the Council of 17 December 2013 establishing rules for direct payments to farmers under support schemes within the framework of the common agricultural policy and repealing Council Regulation (EC) No $637 / 2008$ and Council Regulation (EC) No 73/2009, Official Journal of the European Union, http://g.ekspert.infor.pl/p/_dane/akty_pdf/E0L/2013/347/608.pdf\#zoom=90.

\section{Information about author:}

\section{Dr. Engr. Agnieszka Biernat-Jarka}

Warsaw University of Life Sciences - SGGW

Institute of Economy and Finances

e-mail: biernat-jarka.agnieszka@wp.pl

ORCID: 0000-0003-2497-1656 